\title{
Efficacy of Leaf Extract of Drumstick Tree (Moringa Oleifera Lam.) On The Growth of Local Tomato (Lycopersicon esculentum)
}

\author{
Bashir, K.A. ${ }^{1}$, Bawa, J.A. ${ }^{2}$ And Mohammed, I. ${ }^{3}$ \\ ${ }^{I}$ (Department of Biological Sciences, Federal University Dutsin-Ma, Nigeria) \\ ${ }^{2}$ (Department of Biological Sciences, Federal University Dutsin-Ma, Nigeria) \\ ${ }^{3}$ (Department of Biological Sciences, Federal University Dutsin-Ma, Nigeria)
}

\begin{abstract}
A field study was conducted on the growth of tomato plants with leaf extracts of Moringa oleifera. Different concentrations of the crude extract measured for treatments: A 20\%, B 40\%,C 60\%, D 80\%, and E with $100 \%$. In the treatments used, $100 \mathrm{ml}$ of distilled water was sprayed at the stem base of the plant labeled $F$ which served as control. Four (4) parameters were determined at each week of the experiment i.e. plant height $(P H)$, number of leaves (NL), number of branches (NB) and number of flowers (NF) at five (5) different times. A corresponding increase appeared in the study area. Treatments D (80g/20ml), C $(60 \mathrm{~g} / 40 \mathrm{ml}) B(40 \mathrm{~g} / 60 \mathrm{ml})$ and an average plant height, $A(20 \mathrm{~g} / 80 \mathrm{ml})$. Control was found to have the least of all the growth parameters with an average plant height, leaves number, number of branches and number of flowers of 18.8, 51.0, 9.1 and 1.6. This indicates that, the Moringa leaf extract used significantly increased the growth and yield of tomato plants in all the trials with erect stemming, fresh leaves, regular branching and healthy fruits and regular flowering.
\end{abstract}

Key words: Moringa, Leaf extract, concentrations and tomato

\section{Introduction}

Drumstick tree (Moringa oleifera) is a horse radish tree belonging to the family of Moringaceae, associated with multipurpose attributes, wide adoptability, and ease of establishment. Its leaves, pods, and flowers are packed with nutrients important to both human and animals [1]. M. oleifera is a native to north India but is now found throughout the tropics.

M. oleifera is not a nitrogen fixing tree, but its fruits, flowers and leaves all contain $5 \%$ to $10 \%$ protein on average. All of these parts are eaten widely as vegetables; provide excellent food, for both humans and eaten like green beans. These roots taste similar to horse radish and is popular food (leaves) in the East Africa. M. oleifera flowers also produce a good honey. It has density of 0.5 to 0.7 and yield approximately $4,600 \mathrm{kcaL} / \mathrm{kg}$ [2].

The seeds of Moringa are usually used as anticoagulant [3]. Harvested dry seed are shelled crushed in to powdered form and made in to paste with the water before mixing with more water. The mixed water is then allowed to settle and sieved its turbidity is extensively reduced including hardness reduction [4].

The leaves of Moringa are full of nutrients and vitamins Moringa oleifera leaves were reported to have $25.1 \%$ crude protein, $0.50 \%$ methionine and a metabolisable energy value of $227 \mathrm{kcal} / \mathrm{kg}$ [5]. A survey of over 120 species of tropical and subtropical edible plants for nutrient content, antioxidant activity, and a crop trait indicated that Moringa oleifera is one of the promising crops which could contribute to increased intake of micronutrient and antioxidant. Moringa oleifera leaves can be excellent sources of calcium, potassium and protein [6].

It was also reported that the leaves of Moringa oleifera plants an excellent source of vitamins, mineral and protein perhaps more than any other tropical vegetable. Moringa leaves extract had so been reported to exhibit antimicrobial activities including inhibition for the growth of staphylococcus aureus that are commonly isolated from food and animals intestines, It also has a medicinal uses among the natives [7].

M. oleifera is increasingly becoming popular among communities in Nigeria for use as a vegetable, and for medicinal purposes. In the wake of high cost or skyrocketing global prices and skill labor in application, the land, water pollution and hazardous nature associated with use of inorganic fertilizer and the contribution of inorganic fertilizer to climate change and effect on soil ecosystem, there is a need to search for alternative sources of plant nutrients. M. oleifera is one such alternative being investigated to ascertain its effect on growth and yield of vegetable crops like tomato so that such plants can be promoted as a possible supplement or substitute to inorganic or chemical fertilizer and be promoted as a multipurpose plant that may develop better, safer and cheaper way of increasing the yield of stable vegetable crops indeed tomato for healthy nourishment.

This research was carried out to evaluate the effect of Moringa oleifera leaf extract on the growth and yield of local tomato plants. 


\section{Materials And Method}

The study was conducted at the Biological Science Garden, in Usmanu Danfodiyo University Sokoto Nigeria, from the period of May 2010 - February, 2011. Moringa leaves were collected from the garden, tomato seeds were collected from Kasuwa Daji, in Sokoto Area, and equipment were collected from Mycology laboratory.

\subsection{Treatments}

A total of eighteen (18) polythene bags measuring $12.5 \mathrm{~cm}$ in diameter and $20 \mathrm{~cm}$ high were filled with the garden soil and seeds were planted in 3 replicates. Two types of treatments were carried out; which include treatment with M. oleifera leaves extract and treatment with distilled water, which serve as control. Hence, study on germination and growth of tomato was carried out on the same garden area.

\subsection{Filling Of Poly Bags}

The 18 polythene bags were filled with mixture of soil and manure in a ratio of (2:1). The bags were then watered for the soil to saturate, and all the bags were perforated at their bases, so as to avoid water logging.

\subsection{Raising Of Tomato Seedlings}

A total of 18 poly bags were used in planting the tomato seedlings after collecting the seeds. Seed bed was prepared and was watered for two (2) days. The tomato seeds were then sprayed on the seed bed and covered completely with a neem tree branches to serve as shade for 5-6 days. After fourteen (14) days, they were transplanted in to the polythene bags i.e one seedling per polythene bag. They were arranged randomly in six (6) blocks of 18 plants with different concentrations labeled A, B, C, D, E and F; where A carries $20 \%$, B $40 \%$, C $60 \%$, D $80 \%$, and F $100 \%$ of the crude extract of Moringa oleifera leaves and later, the extract was spread at five (5) different times. The first spread was after the first reading; the 2nd was at the 4th week, third was at 5th week, fourth was at 6th week and fifth was at 7th week. Those labeled F served as control; they were only sprayed with distilled water at the same time.

\subsubsection{Method Of Extraction}

The extract was made by pounding young Moringa leaves (not more than 40 days) together with a bit of water (about $200 \mathrm{~m} 1$ per $1 \mathrm{~kg}$ of fresh leaves). A muslin cloth was used in sieving the decoction. A fine filtrate was obtained, the residue was discarded which served as the crude or stock solution. From the stock, stem out the 5 concentrations. A spraying gun was used to spray the seedlings in each of the polythene bags. About $33.3 \mathrm{mls}$ of the different percentage of the concentration was directly spread on each seedling.

However, the different concentrations referred to as treatments were prepared, viz: $1 \mathrm{~kg}$ of fresh Moringa leaves was pounded and $200 \mathrm{mls}$ of water was added. After extracting the crude, extract measured for treatment A with $20 \%$, B with $40 \%$, C with $60 \%$, D with $80 \%$, and E $100 \%$. One hundred $(100 \mathrm{ml})$ of distilled water collected from mycology laboratory was also sprayed at the stem base of the plant labeled $\mathrm{F}$ at the same time which serves as control.

\subsubsection{Measurement And Analysis Of Data}

The plants were watered regularly with tap water. The following four (4) parameters were determined at each week of the experiment i.e. plant height (cm)-PH, number of leaves-NL, number of branches-NB and number of flowers-NF.All data on observations were recorded using descriptive statistics and one way analysis of variance, ANOVA.

\section{Results}

The application of different rates of Moringa oleifera leaf extract and water mixture to the tomato plants at the duration of five (5) weeks with parameters were determined and readings were taken for six (6) weeks from 0 to five weeks, which depends on the volume of extracts used in the growth of local tomato plants as seen in Table 1.

Table 1: Different concentrations of Moringa leaf extract

\begin{tabular}{|c|c|c|}
\hline Concentrations of extracts & $\begin{array}{c}\text { Volume of undiluted Moringa leaves } \\
\text { extract (\%) }\end{array}$ & $\begin{array}{c}\text { Volume of water used to dilute the extract } \\
\text { (mls) }\end{array}$ \\
\hline $\mathrm{A}(20 / 80)$ & 20 & 80 \\
\hline $\mathrm{B}(40 / 60)$ & 40 & 60 \\
\hline $\mathrm{C}(60 / 40)$ & 60 & 40 \\
\hline $\mathrm{D}(80 / 20)$ & 80 & 20 \\
\hline $\mathrm{E}(100)$ & 100 & - \\
\hline $\mathrm{F}$ & Control & $100 \mathrm{ml}$ of distilled water only. \\
\hline
\end{tabular}


During the first week, the average plant height was $15.1 \mathrm{~cm}$ with $20 \%$, concentration of the leaf extract. This increased to 20.6 at the $2^{\text {nd }}$ week. The plant height was $21.4,26.5$, and $28.8 \mathrm{~cm}$ during the $3^{\text {rd }}, 4^{\text {th }}$ and $5^{\text {th }}$ weeks respectively. The average plant height was 15.3 at the $1^{\text {st }}$ week with $40 \%$, concentration of the leaf extract. This increased to $21.6,22.4,27.4,30.1 \mathrm{~cm}$ during the $2^{\text {nd }} 3^{\text {rd }} 4^{\text {th }}$ and $5^{\text {th }}$ weeks respectively as indicated in Table 2. The average plant height was 16.3 at the $1^{\text {st }}$ week with $60 \%$, this increased to $23.3,23.6,29.8$ and $33.4 \mathrm{~cm}$ during the $2^{\text {nd }}, 3^{\text {rd }}, 4^{\text {th }}$ and $5^{\text {th }}$ weeks respectively Table 2 . The average plant height was $17.0 \mathrm{~cm}$ at the $1^{\text {st }}$ week with $80 \%$, concentration of the leaf extract; this increased to $23.8,25.7,31.7$ and $36.0 \mathrm{~cm}$ during the $2^{\text {nd }} 3^{\text {rd }}$ $4^{\text {th }}$ and $5^{\text {th }}$ weeks respectively. The average plant height was 18.0 at the $1^{\text {st }}$ week with $100 \%$, concentration of the leaf extract. This increased to $25.5,27.6,34.6$ and $40.8 \mathrm{~cm}$ during the $2^{\text {nd }}, 3^{\text {rd }}, 4$ th and $5^{\text {th }}$ weeks respectively Table 2.

Table 2: Effect of different concentrations of Moringa oleifera leaf extract on the plant height of tomato plant seedlings $(\mathrm{cm})$

$\mathrm{PH}=$ Plant height

\begin{tabular}{|c|c|c|c|c|c|}
\hline $\begin{array}{c}\text { Concentrations } \\
(\%)\end{array}$ & $\begin{array}{c}1 \\
\text { PH }\end{array}$ & $\begin{array}{c}2 \\
\mathrm{PH}\end{array}$ & $\begin{array}{c}3 \\
\mathrm{PH}\end{array}$ & $\begin{array}{c}4 \\
\mathrm{PH}\end{array}$ & $\begin{array}{c}5 \\
\mathrm{PH}\end{array}$ \\
\hline 20 & 15.1 & 20.6 & 21.4 & 26.5 & 28.8 \\
\hline 40 & 15.3 & 21.6 & 22.4 & 27.4 & 30.1 \\
\hline 60 & 16.3 & 23.3 & 23.6 & 29.8 & 33.4 \\
\hline 80 & 17.0 & 23.8 & 25.7 & 31.7 & 36.0 \\
\hline 100 & 18.0 & 25.5 & 27.6 & 34.6 & 40.8 \\
\hline $\mathrm{AV}$ & 16.3 & 23.0 & 24.2 & 30.0 & 33.3 \\
\hline
\end{tabular}

The result in Table 3 shows that in the first week, the average leaf number was 31.3 with $20 \%$, concentration of the leaf extract. This increased to 38.7 at the $2^{\text {nd }}$ week. The leaves number was 487 . 71.7 and 122.0 during the $3^{\text {rd }} 4^{\text {th }}$ and $5^{\text {th }}$ weeks respectively. The average leaves number was 34.3 at the $1^{\text {st }}$ week with $40 \%$, concentration of the leaf extract Table 3. This increased to $42.4,50.0,97.7$ and 171.3 during the $2^{\text {nd }}, 3^{\text {rd }}$, $4^{\text {th }}$ and $5^{\text {th }}$ weeks respectively. The average leaves number was 36.3 at the first week with $60 \%$, concentration of the leaf extract. This increased to $52.0,66.3,110.3$ and 175.3 during the $2^{\text {nd }}, 3^{\text {rd }}, 4^{\text {th }}$ and $5^{\text {th }}$ weeks respectively Table 3. The average leaves umber was 42.3 at the first week with $80 \%$, concentration of the leaf extract. This increased to $66.7,82.0,136.7$ and 206.7 during the 2 nd $3 \mathrm{rd} 4$ th and 5 th weeks respectively. The average leaves number was 2.3 at the $1^{\text {st }}$ week with $100 \%$, concentration of the leaf extract. This increased to 81.7, 91.0, 160 and 236.0 during the $2^{\text {nd }}, 3^{\text {rd }} 4^{\text {th }}$ and $5^{\text {th }}$ weeks respectively Table 3.

Table 3: Effect of different concentrations of Moringa oleifera leaf extract on the leaves number of tomato plant seedlings

\begin{tabular}{|c|c|c|c|c|c|}
\hline $\begin{array}{c}\text { Concentrations } \\
(\%)\end{array}$ & 1 & 2 & 3 & 4 & 5 \\
\hline 20 & LN & LN & LN & LN & LN \\
\hline 40 & 31.3 & 38.7 & 48.7 & 71.7 & 122.0 \\
\hline 60 & 34.3 & 42.3 & 50.0 & 97.7 & 171.3 \\
\hline 80 & 36.3 & 52.0 & 66.3 & 110.3 & 175.3 \\
\hline 100 & 38.7 & 66.7 & 82.0 & 136.7 & 206.7 \\
\hline $\mathrm{AV}$ & 42.3 & 81.7 & 91.0 & 160.0 & 236.0 \\
\hline & 36.6 & 56.3 & 67.6 & 115.3 & 182.3 \\
\hline
\end{tabular}

$\mathrm{LN}=$ Leaf Number

The result in Table 4 indicates that during the $1^{\text {st }}$ week, the average number of branches was 4.7 with $20 \%$, concentration of the leaf extract. This increased to 7.0 at the $2^{\text {nd }}$ week. The number of branches was 10 , 14.3 and 18 during the $3^{\text {rd }}, 4^{\text {th }}$ and $5^{\text {th }}$ weeks respectively. The average number of branches was 5.3 at the $1^{\text {st }}$ week with $40 \%$, concentration of the leaf extract. This increased to $8.3,9,15$ and 18.7 during the $2^{\text {nd }}, 3^{\text {rd }}, 4^{\text {th }}$ and $5^{\text {th }}$ 'weeks respectively. The average number of branches was 6.7 at the first week with $60 \%$, concentration of the leaf extract. This increased to $9.7,12.7,16$ and 19.7 during the $2^{\text {nd }}, 3^{\text {rd }}, 4^{\text {th }}$ and $5^{\text {th }}$ weeks respectively Table 4. The average number of branches was 7 at the $1^{\text {st }}$ week with $80 \%$, concentration of the leaf extract. This increased to $10.7,14,18.7$ and 21.7 during the 2 nd 3rd 4th and 5th weeks respectively. The average number of branches was 9.7 at the $1^{\text {st }}$ week with $100 \%$, concentration of the leaf extract. This increased to 13.3, 17, 20.7 and 23.7 during the $2^{\text {nd }}, 3^{\text {rd }}$ and $5^{\text {th }}$ weeks respectively Table 4. 
Table 4: Effect of different concentrations of Moringa oleifera leaf extract on the number of branches of tomato plant seedlings

\begin{tabular}{|c|c|c|c|c|c|}
\hline $\begin{array}{c}\text { Concentration } \\
(\%)\end{array}$ & 1 & 2 & 3 & 4 & 5 \\
\hline 20 & NB & NB & NB & NB & NB \\
\hline 40 & 4.7 & 7.0 & 10.0 & 14.3 & 18.0 \\
\hline 60 & 5.3 & 8.3 & 9.0 & 15.0 & 18.7 \\
\hline 80 & 6.7 & 9.7 & 12.7 & 16.0 & 19.7 \\
\hline 100 & 7.0 & 10.7 & 14.0 & 18.7 & 21.7 \\
\hline AV & 9.7 & 13.3 & 17.0 & 20.7 & 23.7 \\
\hline & 6.7 & 9.8 & 12.5 & 16.9 & 20.4 \\
\hline
\end{tabular}

$\mathrm{NB}=$ Number of Branches

In the $1^{\text {st }}, 2^{\text {nd }}$ and $3^{\text {rd }}$ weeks, flowers were not observed with $20 \%$, but during the $4^{\text {th }}$ and $5^{\text {th }}$ weeks flowers were been observed with the average number of 2.7 and 8 respectively. During the first week of $40 \%$, no flowers observed, but in the $2^{\text {nd }}, 3^{\text {rd }}, 4^{\text {th }}$ and $5^{\text {th }}$ weeks, flowers were observed with an average number of 1.2 , 8 and 3.7 respectively Table 5. During the first week of $60 \%$, no flowers observed, but during the $2^{\text {nd }}, 3^{\text {rd, }} 4$ th and $5^{\text {th }}$ weeks flowers were observed with an average number of $2.7,5.3,10.7$ and 17.7respectively. During the $1^{\text {st }}$ week of the $80 \%$, no flowers observed, but during the $2^{\text {nd }}, 3^{\text {rd }}, 4^{\text {th }}$ and $5^{\text {th }}$ weeks flowers were observed with an average number of $4.3,8.3,14.3$ and 20.7 respectively. During the $1^{\text {st }}$ week of $100 \%$, no flowers observed, but during the $2^{\text {nd }} 3^{\text {rd }}, 4^{\text {th }}$ and $5^{\text {th }}$ weeks flowers were observed with average of 5.3, 8.7, 15 and 23 as seen in Table 5.

Table 5: Effect of $80 \mathrm{~g} / 20 \mathrm{ml}$ Leaf concentration of Moringa oleifera plant on the growth of Tomato plants

\begin{tabular}{|c|c|c|c|c|c|}
\hline $\begin{array}{c}\text { Concentration } \\
(\%)\end{array}$ & 1 & 2 & 3 & 4 & 5 \\
\hline 20 & $\mathrm{NF}$ & $\mathrm{NF}$ & $\mathrm{NF}$ & $\mathrm{NF}$ & $\mathrm{NF}$ \\
\hline 40 & 0 & 0 & 0 & 2.7 & 8 \\
\hline 60 & 0 & 1 & 2 & 8 & 13.7 \\
\hline 80 & 0 & 2.7 & 5.3 & 10.7 & 17.7 \\
\hline 100 & 0 & 4.3 & 8.3 & 14.3 & 20.7 \\
\hline $\mathrm{AV}$ & 0 & 5.3 & 8.7 & 15.0 & 23.0 \\
\hline
\end{tabular}

$\mathrm{PH}=$ Plant height, $\mathrm{LN}=$ Leaves Number, $\mathrm{NB}=$ Number of branches and $\mathrm{NF}=$ Number of flowers.

Results in Table 6 served as control, in which the plant height at the $1^{\text {st }}$ week was $13.0 \mathrm{~cm}$; leaves number 29.7, number of branches 5 and no flowers were observed. In the $2^{\text {nd }}$ week further readings increased, as noticed with plant height of $16.1 \mathrm{~cm}$, leaves number of 39.7 , number of branches 6.3 and no flowers were observed respectively. There is also an increase in the $3^{\text {rd }}$ week with plant height of $20.1 \mathrm{~cm}$, leaves number of 44, number of branches 8.7 and 0 respectively. Further increase at the $4^{\text {th }}$ week was noticed with plant height of $24.7 \mathrm{~cm}$, leaves number of 65.7 , number of branches 13 and number of flowers was 2.3 respectively. Another increase was noticed in the $5^{\text {th }}$ week with plant height of $27.4 \mathrm{~cm}$, leaves number 103.3 , number of branches 16 and number of flowers 7 Table 6.

Table 6: Effect of control on the growth of tomato plants

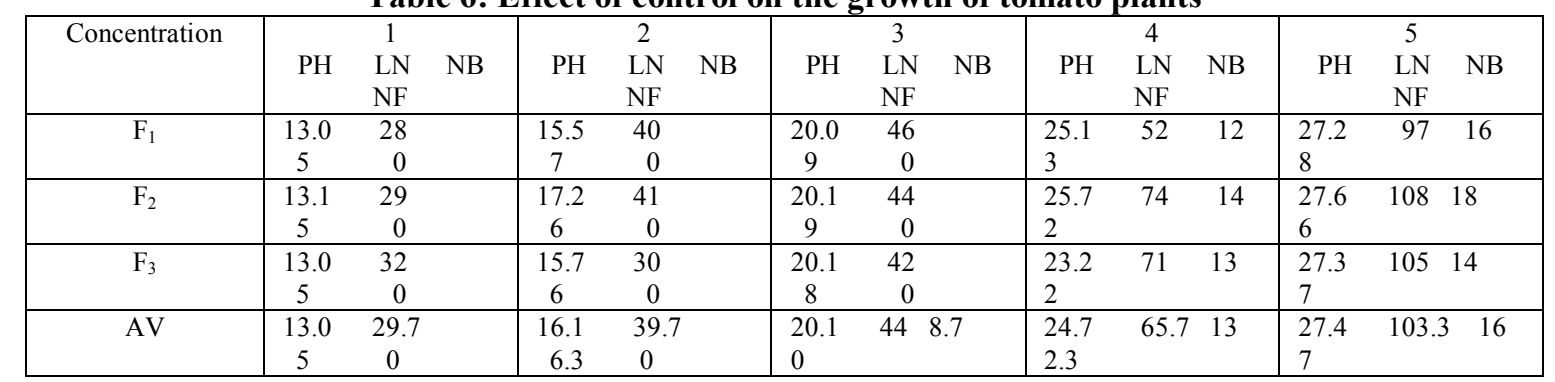

$\mathrm{PH}=$ Plant Height, $\mathrm{LN}=$ Leaves Number, $\mathrm{NB}=$ Number of Branches and NF $=$ Number of flowers. 
Table 7: The mean (average) of all the treatments with different concentrations on the growth of tomato plants

\begin{tabular}{|c|c|c|c|c|c|c|c|}
\hline & $\mathrm{A}$ & $\mathrm{B}$ & $\mathrm{C}$ & $\mathrm{D}$ & $\mathrm{E}$ & $\mathrm{F}$ & $\mathrm{SE}$ \\
\hline $\begin{array}{c}\text { 1. Plant height } \\
(\mathrm{cm})\end{array}$ & 19.9 & 21.6 & 23.2 & 24.4 & 26.8 & 18.8 & 3.26 \\
\hline $\begin{array}{c}\text { 2. Number of } \\
\text { leaves }\end{array}$ & 55.4 & 71.0 & 77.6 & 91.0 & 96.1 & 51.0 & 18.30 \\
\hline $\begin{array}{c}3 . \text { Number of } \\
\text { branches }\end{array}$ & 9.6 & 10.6 & 11.4 & 12.6 & 14.7 & 9.1 & 2.10 \\
\hline $\begin{array}{c}\text { 4. Number of } \\
\text { flowers }\end{array}$ & 1.8 & 4.3 & 6.1 & 7.9 & 9.0 & 1.6 & 3.10 \\
\hline
\end{tabular}

\section{Discussion}

The increase in plant parameters namely; the plant height, leaves number, number of branches, and number of flowers as a result of extracts used in this research significantly increased the growth of tomato plants used in this research. This luxuriant growth of the tomato plants might be due to the volume of concentration (up to $100 \%$ ) of Moringa oleifera extracts used. The magnitude of increase which appeared might depend mainly on the concentrations used, and increase in concentration yielded a simultaneous increase up to the limit in the above growth parameters. Plant extracts of some trees and crop residues have been reported to influence crop growth and yield vegetable crops $[8 ; 9 ; 10 ; 11 ; 12]$. Leaf extracts of M. oleifera have been reported to accelerate growth of young plants, strengthen plants, increase leaf area duration, increase number of roots, produce more and larger fruits and generally increase yield by 20 to $35 \%$ [13]. It has been established in this research that average plant height was initially $16.3 \mathrm{~cm}$, which increased to $23.0,24.2,30.0$ and $33.3 \mathrm{~cm}$. Leaf number also increased to 56.3, 67.6, 115.3 and 182.3. It could be deduced that the chemical components incorporated in the extracts used might be responsible to inhabit the development of these tomato plants in comparison with the control treatments. Both the plant height and leaf number increase with the constant application of the Moringa leaf extracts at $80 \%$ concentrations with regular plant height $(40.8 \mathrm{~cm})$ and leaf number (236.0). This could also be explained that M. oleifera leaf extracts enhanced the germination of tomato plants by $20-80 \%$. [14] reported that aqueous extract of $\mathrm{M}$. oleifera at the ratio of 1:10 (w/v) prepared in a $30 \mathrm{~g}$ of plant leaf material with $300 \mathrm{ml}$ of distilled water was found to influence the duration of height and hypocotyls growth in tomato and sorghum. The leaf extracts of M. oleifera also gave higher (100\%), vigorous and good quality of tomato seedlings in height, leaf number and flowering. [15] demonstrated that incorporation of dried sunflower leaf material into the soil; treatment with aqueous extract, root exudates and leaf leachates inhibited germination and growth of grain sorghum (Sorghum bicolor) and tomato (Lycopersicon esculentum).

It was reported from this research that, the average number of branches was 6.7 up to 20.4. It was also revealed that during the 1st week, no flowers were observed, and the average number of flowers was 9.8 but continue to increase to $12.5,16.9$ and 20.4. This could be explained by the fact most of the tomato plants grown in the trials are highly sensitive to the extracts used followed by the influence of the weather and condition of the soils which may seem to be more in retaining moisture contents and leaf extracts. The improvement in growth parameters of tomato plants in response to shikimic acid application is mediated through the increased longevity of leaves and branches by retaining chlorophylls and increasing mineral contents which perhaps contributed to increased plant growth [16]. In addition, the results obtained here are in accordance with the results of [17] who stated that seed priming with shikimic acid and Moringa root extract increased growth and yield of cowpea plants grown under greenhouse conditions through photosynthetic activity.

In this work, it was reported that treatment $\mathrm{E}$ had the highest $(26.8,96.1,14.7$ and 9.0) numbers of growth parameters of the tomato plants. It was therefore, found to be the most appropriate concentration for increasing the healthy vegetative growth and parameters of the tomato plants. This was probably due to the high concentration of the growth promoting substances contained in this treatment. The effect of Moringa leaves extract in stimulating plant growth was reported by [18].

It was also observed that treatment $\mathrm{D}(80 \mathrm{~g} / 20 \mathrm{ml})$ with an average plant height leaves number, number of branches, and number of flowers of 24.4, 91.0. 12.6 and 7.9. This indicates that reduction in the concentration of Moringa oleifera leaves extract might have affected the growth of tomato plants. It was also observed that treatment $\mathrm{C}(60 \mathrm{~g} / 40 \mathrm{~m} 1)$ followed with an average plant height, leaves number, number of branches and number of flowers of 23.3, 77.6, 11.4 and 6.1 respectively. But, treatment B (which is $40 \mathrm{~g} / 60 \mathrm{ml}$ ) followed with an average plant height, leaves number, number of branches and number of flowers of 21.6, 72.0, 10.6 and 4.3 respectively. It was also observed in treatment A $(20 \mathrm{~g} / 80 \mathrm{ml})$ followed with an average plant height, leaves number, number of branches and number of flowers of 19.9, 55.4, 9.6 and 1.8 respectively having the least growth promoting substances among treatments with Moringa leaves extract. Control was found to have the least of all the growth parameters with an average plant height, leaves number, number of branches and number of flowers of 18.8, 51.0, 9.1 and 1.6. Meanwhile, those that were not statistically different from the controls 
might be due to inhibition of the growth of tomato plants which is generally related to changes in the plants water status and ability to retain the leaf extracts.

This supports the report of [19] who noticed that, application of Moringa root and leaf extract by 2-4 weeks after planting significantly $(\mathrm{p}<0.05)$ increased fresh fruit weight and number of stem, flowers and branches of the tomato plants. Plant residues often contain a variety of toxins that are known inhibitors of seed germination or seedling growth $[20 ; 21]$. Recycling crop residue and leachates from plants to the soil have been reported to inhibit seed germination and vegetative propagules, and early seedlings growth in tomatoes [22; 23]. With this vision, [24] applied Moringa oleifera leaf extracts in the ratio of 1:10 (w/v) on seeds of maize, rice, sorghum and wheat in a growth room at $25^{\circ} \mathrm{C}$ for 14 days and found that it not only increased the length of radicalbut also increased hypocotyl length of maize and wheat. It was reported that this hormone application as a seed treatment not only improved the vegetative growth but also enhanced the grain yield even applied in very small amounts as a seed treatment.

\section{Conclusion}

Moringa oleifera leaves extract contained growth promoting substances. When applied on the foliage of tomato plants, it showed an appreciable level of growth. Application of the extracts at $100 \mathrm{~g} / 0 \mathrm{ml}$ was found to be the best concentration for stimulating growth of tomato plants. However, even the least concentration of $20 \mathrm{~g} / 80 \mathrm{ml}$ showed promising results in the growth parameters studied. In the field experiments, it may be concluded the higher the frequency of Moringa application, the greater the increase in plant height, erect stemming, good branching, fruits yield and regular flowering of the crop. Furthermore, the control had the least growth of all the parameters, investigated, as it has no extract that contained growth promoting substances.

\section{References}

[1]. R. Dalla, Food value of the lesser utilized Tropical plant, Food Chemical Society, 46, 1993, 239-246.

[2]. L.J. Fuglie, The Miracle tree Moringa oleifera: Natural nutrition for the Tropics(Church World Service: Daka Senegal Pp 63, 1999).

[3]. M.E. Olson, Moringaceae: Drumstick Family in Flora of North America Editorial Committee, eds. Flora of North America North of Mexico, 15(7), 2010, 167-169.

[4]. S.A. Muyibi, L.M. Evison, Optimizing physical parameters affecting coagulation of turbidity waters with Moringa oleifera Seeds Water Research, 29: 1995, 2689-2695

[5]. H.P.S. Makker, K. Becker, Nutrient and quality factor in different morphological parts of the Moringa oleifera tree Journal of Agricultural Science Cambridge, 12: 19997, 311-322

[6]. J.F. Morton, The horse radish tree Moringa Ptercygcos Perma (Moringaceae).A Book to Arid Land (Econ-linban Publishers 45, 1991, 318-333)

[7]. S.G. Hussein, and M.B. Abbaro, The influence of prunings of Leucaena leucocephala and Eucalyptus microtheca used as green manure mulch on growthand yield of fodder sorghum (Sorghum bicolor L.) University of Khartoum Journal of Agricultural Science 5, 1997, 106-114

[8]. M. Farooq, K. Jabran, H. Rehman, and M. Hussain, Allelopathic effects of rice on seedling development in wheat, oat, barley and berseem Allelopathy Journal, 22, 2008, 385-390

[9]. D.M. Ahmed, and A.M. Nimer, Effects of Acacia senegal (L., Wild) on sandy soils. A case study of El Damokya Forest, Northern Kordofan State University Khartoum. Journal Agricultural Science, 10, 2002, 106-118

[10]. H.A. El Atta, and L.A. Bashir, Adverse effects of Eucalyptus camaldulensis (Dehn) leaf extract on germination and seedling growth of wheat, University Khartoum Journal of Agricultural Science, 7, 1999, 70-79

[11]. M. Chung, and D.A. Miller, Allelophathic influence of nine forage grasses on germination and seedling growth of alfalfa. Agronomy Journal, 87, 1995, 767-782

[12]. W.D. Guenzi, T.M. Mc-Calla and F.A. Norstadt, Presence and persistence of phytotoxic substances in wheat, oat, corn and sorghum residues Agronomy Journal, 59, 1967, 163-165

[13]. L.J. Fuglie, The Miracle Tree: Moringa oleifera: Natural Nutrition for the Tropics (Lowell J. Fuglie, CTA, Wageningen, Netherlands 2000, Pp172)

[14]. N. Foidl, H.P.S. Makkar, and K. Becker, The potential of Moringa oleifera for agricultural and industrial uses, In: The Miracle Tree: (The Multiple Attributes of Moringa (Ed) Lincon Publishers XP, 2001, pp 45-76)

[15]. M. K. Schon, and F.A. Einhellig, Allelopathic effects of cultivated sunflower on grain Sorghum. Bot. Gaz. $143,1982,505-510$.

[16]. W. Zakaria, and A.R. Razak, Effects of groundnut plant residues on germination and radicle elongation of four crop species. Pertanika, 13, 1990, 297-302

[17]. G.A. Wicks, D.A. Crutchfield, and O.C. Burnside, Influence of wheat (Triticum aestivum) straw mulch and metolachlor on corn (Zea mays) growth and yield. Weed Science Journal, 42, 1994, 141-147

[18]. A.B. Hall, U. Blum, and R.C. Fites, Stress modification of allelopathy of Helianthus annuus L. debris on seed germination. American of Journal Botany, 69, 1982, 776-783

[19]. M. Culver, T. Fanuel and A.Z. Chiteka, Effect of Moringa Extract on Growth and Yield of Tomato, Greener Journal of Agricultural Sciences, 2 (5), 2012, 207-211.

[20]. C.H. Chov, Z.A. Patrick, Identification and phytotoxic activity of compounds produced during decomposition of corn and rye residue in the soil. Journal of Chemical Ecolology. 3, 1976, 365 - 367.

[21]. M. An, J.E. Pratley, P. Jellett, Genotypic variation of plant species to the allelopathic effects of vulpia residues. Australian Journal of Experimental Agriculture, 37 (6) 1997, 647-660.

[22]. C.M. Babu, O.S. Kandasanmy, Allelopathic effects of Eucalyptus globulus Labill.on Cyperus rotundus L. and Cynodon dactylon L. pers. Journal of Agronomy and Crop Science 179 (2) 1997, 123-126.

[23]. S.R. Dhwan, and S.K. Gupta, Allelopathic potential of various leachate combinations towards SG and ESG of Parthenium hysterophorus Linn. World Weeds Journal, 3 (1), 1996, 85 - 88. 